\title{
Sectoral Contribution of FDI in India (With special reference to Automobile, Telecommunication, Services and Computer Hardwares \& Softwares sectors)
}

\author{
S. Prasad, A. Paul Williams
}

\begin{abstract}
After opening of the Indian economy, the contribution of Foreign Direct Investment to the Indian Economy is remarkable. The Foreign Investments not only brings in capital into the host country but also the technological advancements, best practices in managing the company and also efficiency. The Government of India is concentrating on attracting the FDI more than the FII. This is because Foreign Direct Investment is more stable and it has a presence in the host country. On the other hand, FIIs are unstable and they invest in the shares of the company and also they move out the capital when the market conditions are not favourable for them. Also the Government of the day is focusing on attracting more Foreign Direct Investments. This is evident from the jump in the Ease of Doing Business Index rank of India in the recent report. This article tries to analyse the Sectorwise contribution (Automobile, Telecommunication, Services and Computer Hardwares \& Softwares sectors) of FDI in the Indian economy. The analytical tools such as regression and correlation have been used. The results show that the computer hardware and software sector has contributed the most to the GDP of India among the sectors considered. The least contributor is the Telecom Sector. The study has also given some suggestions to the policy makers so that the different sectors of the economy remain attractive to the FDI.
\end{abstract}

Keywords : FDI, Sectors, Indian Economy, Ease of Doing Business.

\section{INTRODUCTION}

The Indian Economy was a late entrant into the already integrated and globalized economies. This is because, the leaders of the early independent India was hesitant towards the concept of opening up the sectors of economy. They were of the opinion that foreign capital was the main reason behind the colonial powers and their subsequent conquest of other Nations. This discouraged the Indian leaders from opening the economy. But the country could not be kept in isolation for long, since the benefits from integrating with the other economies were threefold compared to a conservative one. The time came around 1991, when the country was facing Balance of Payment crisis, the multilateral financial institutions such as the IMF and World Bank were ready to support the Indian Government but under one condition that the country should open up its economy. Hence the era of

Revised Manuscript Received on September 25, 2019

Dr.S.Prasad, Assistant Professor, Dept of International Business, Alagappa University, Karaikudi

A.Paul Williams, Ph.D Scholar, Dept of International Business, Alagappa University, Karaikudi.
Liberalization, Globalization and Privatization begun in our nation's history. From then on, our country has progressed in an unimaginable way. Also the leaders were conscious in opening up different sectors of the economy. Now with the time, most of the sectors of Indian Economy is open to Foreign Direct Investment. This study will analyze the selected sectors contribution of FDI in India and the impact of policy changes in attracting the FDI.

\section{REVIEW OF LITERATURE}

Joo, Bashir \& Ali Dhar, Faiza. (2018) in their article has analyzed how sector specific FDI contribution has contributed to the economic growth of India. Also they have tried to analyse the effect of the FDI inflows in a particular sector on the growth and to which extent the FDI inflows affects the Growth of the country. In their study they have found that almost all sectors FDI inflows has a positive impact on GDP except three. These three are the Computer Hardware \& Software, Power and Drugs \& Pharmaceuticals. They have suggested the Indian Policymakers to adopt innovative policies to attract FDI by making the exit easy for the companies. Chengalvala, Sarada. (2017) in her paper has analyzed the FDI inflows for a period of seventeen years from 2000 till 2017. In her study she has found that there is a steady increase in the flow of FDI into the Indian Economy. The study also appreciates the liberalization of Indian economy in the 1990s which attracted huge investments. Another important finding of the study is that the Global meltdown during the 2008-2010, did not have any negative impact on the Foreign Investment Inflows into the economy. Singhania, Monica \& Gupta, Akshay. (2011) have tried to find the determinants of FDI in India. They have tried to find out the best fit model such as ARIMA to explain the variation in the FDI. The results show that among the macroeconomic variables considered, only GDP, Inflation and Scientific Research are the significant factors that affect the FDI inflows. Also they have stated that the FDi policy changes during the years 1995-1997 have significantly increased the FDI Inflows into India. Aykut, Dilek \& Sayek, Selin. (2007). have studied the sectoral distribution of FDI in many countries. They have also analyzed the magnitude of absolute level of FDI inflows and relative level of FDI inflows in each sector. They have concluded that positive relationship between economic growth and all types of FDI. Lect. Ping Zheng, Sen. (2013). In their study has found that the economic and structural transformations in the

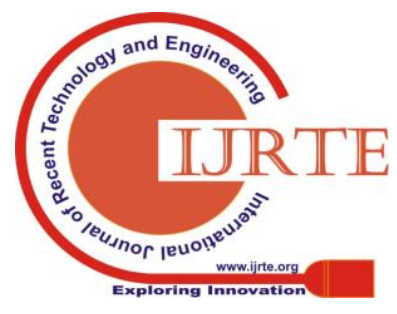




\section{Sectoral Contribution Of Fdi In India \\ (With special reference to Automobile, Telecommunication, Services and Computer Hardwares \& Softwares sectors)}

Indian Economy has significantly impacted the foreign investment inflows. They have also suggested that targeted policies by the Government of India are necessary for attracting investments in the future.

\section{NEED FOR THE STUDY}

The countries around the world are now, well integrated economically. This is visible even when a small internal problem erupts, it will be reflected in the distortion of foreign capital inflows. Hence it is important for a country to be well aware of the problems that exists in the international arena and also the host country should be careful while formulating policies for its own country. The study will help in analyzing the trends in FDI across selected sectors. By doing so, the sectors which are less attractive can be identified and the inputs can be given to policy makers as well as the market players to accommodate the needs of the investor. The knowledge on sector wise inflows of FDI will enable us to plan our policies accordingly which will be attractive for the investors. The recent tensions also pose a serious threat to the Foreign Investments since they affect the trust of the investors and hence it is important to know about the current happenings around the world.

\section{OBJECTIVES OF THE STUDY}

- To assess the relationship of FDI Inflows across Selected sectors of Indian Economy vis-à-vis the GDP of Indian Economy.

- To determine the influence of FDI inflows in selected sectors on the GDP.

- To give inputs to policy makers regarding the measures that will improve the FDI inflows in the selected sectors.

\section{RESEARCH METHODOLOGY}

a. PERIOD OF STUDY

The study was conducted for a period of 11 years from 2008 till 2018.

\section{b. SOURCES OF DATA}

The data used for the study is of secondary in nature.

\section{c. ANALYTICAL TOOLS USED IN THE STUDY}

The necessary tools such as Regression and Correlation are used

\section{DATA ANALYSIS AND INTERPRETATION}

The researchers have analysed the data from the Indiastat website for a period of eleven years and they have considered four sectors FDI inflows and its relationship and influence on the GDP of India. The relationship between the considered independent variable and the dependent variable has been analysed using correlation and the influence of independent variables on the dependent variable is found out using linear regression by ordinary least square. The impact of FDI inflows in selected sectors on the GDP of India is calculated using the following equation

\section{GDP $_{\mathrm{i}}=\alpha_{0}+\alpha_{1}$ SERVICESFDI $+\alpha_{2}$ TELECOMFDI $+\alpha_{3}$ AUTOFDI $+\alpha_{4}$ COMPFDI $+\mu_{i}$}

\section{Hypotheses:}

$\mathbf{H}_{\mathbf{0}}$ : There is no significant relationship between FDI inflows in Service sector and GDP of India.

$\mathbf{H}_{\mathbf{1}}$ : There is no significant relationship between FDI inflows in Telecommunication sector and GDP of India.

$\mathbf{H}_{3}$ : There is no significant relationship between FDI inflows in Automobile sector and GDP of India.

$\mathbf{H}_{\mathbf{4}}$ : There is no significant relationship between FDI inflows in Computer Hardware \& Software sector and GDP of India.

Table 1: Correlation

\begin{tabular}{|c|l|r|r|r|r|}
\hline \multicolumn{2}{|c|}{ SECTORS } & \multicolumn{1}{c|}{ Services } & \multicolumn{1}{c|}{ Telecom } & \multicolumn{1}{c|}{ Automobile } & \multicolumn{1}{c|}{ Computer H/S } \\
\hline GDP & $\begin{array}{l}\text { Pearson } \\
\text { Correlation }\end{array}$ & .564 & .495 & $.698^{*}$ & $.806^{* *}$ \\
\hline & Sig. (2-tailed) & .071 & .122 & .017 & .003 \\
\hline
\end{tabular}

Source: Researchers computed using spss 20.

**Correlation is significant at the 0.01 level (2-tailed).

*Correlation is significant at the 0.05 level (2-tailed).

From table 1, the relationship between FDI inflows in services \& telecommunication sector and GDP of India is not significant $(\mathrm{p}>0.05)$. Hence in both the cases null hypothesis has been accepted. The next two sectors' FDI inflows (automobile and computer hardware \& software) has a significant relationship with the GDP of India $(p<0.05)$. Hence the null hypothesis for both the cases has been rejected.

Table 2: Regression Analysis of selected sector's FDI inflows on GDP of India: 


\begin{tabular}{|c|c|c|c|c|c|c|c|c|}
\hline \multirow[t]{2}{*}{ SECTORS } & \multicolumn{2}{|c|}{ Coefficient } & \multicolumn{2}{|c|}{ t-Statistic } & \multicolumn{2}{|c|}{ Prob. } & \multirow[t]{2}{*}{$\mathbf{R}^{2}$} & \multirow[t]{2}{*}{ F-statistic } \\
\hline & $\mathrm{C}$ & & $\mathrm{C}$ & & $\mathrm{C}$ & & & \\
\hline Services & 1.28 & 1.22 & 3.64 & 2.04 & .005 & .0706 & .31 & 4.20 \\
\hline Telecom & 1.61 & 1.33 & 6.57 & 1.70 & .000 & .1216 & .24 & 2.92 \\
\hline Automobile & 1.05 & 5.22 & 3.16 & 2.92 & .011 & .0168 & .48 & 8.57 \\
\hline ComputerH/S & 1.51 & 1.63 & 10.63 & 4.08 & .00 & .0028 & .64 & 16.65 \\
\hline
\end{tabular}

Source: Researchers computed using Eviews 7

From the above regression model, the results from the correlation for the first two sectors (services and telecommunication) has been confirmed, and there is positive influence on GDP of India but the effect is not significant. For the next two sectors (automobile and computer hardware \& software) there is positive and significant effect on the GDP of India. This also confirms the previous results we got using correlation. The R square for automobile sector shows that 48 percent variation is caused by the FDI inflows on that particular sector on the GDP. The R square for computer hardware \& software sector shows that 64 percent variation is caused on the GDP of India by the FDI inflows in that particular sector.

\section{CONCLUSION}

With the recent trade tensions amongst the major powers such as the USA and China, it is important to know the status of FDI inflows in selected sectors of our own economy. The study shows that the even though the FDI inflows in Services sector remain the highest in absolute value but its influence on the GDP of Indian Economy is not significant. This is because of the outsourcing that happens in the service sector wherein the domestic companies work for the foreign companies, thereby eliminating the need for having a subsidiary in India. Also the telecommunication sector FDI inflows did not significantly influence the GDP of India. This result can be interpreted in good as well as bad ways. The good thing is that the domestic players are good enough in that sector. For example in the recent times, the JIO network has made this telecommunication sector accessible to sections of society. The bad side is that the investor lacks confidence in the sector and hence it is not contributing significantly to the GDP of India. The highlight of the study is the significant influence of FDI inflows in services sector on the GDP. Even the government is keen on overtaking China in the computer hardware \& software sector. With the result we can conclude that the efforts of the government are bearing fruits. Hence the policymakers should continue in the right direction in gaining the investors confidence. Automobile sector FDI inflow is also significantly influencing the GDP. This shows that the government initiatives such as MAKE IN INDIA and INVEST IN INDIA are effective. But the policymakers should identify the bottlenecks in the other two sectors and attract the foreign investors.

\section{ACKNOWLEDGEMENT}

The research paper is funded by RUSA (Rashtriya Uchchatar Shiksha Abhiyan) Phase 2.0 Scheme by Ministry of Human Resource Development (MHRD), India The authors are filled with gratitude to the anonymous referees of the journal for their useful suggestions to refine the paper quality.

\section{REFERENCES}

[1] Joo, Bashir \& Ali Dhar, Faiza. (2018)," Role of Sectorwise FDI Inflow on Growth of India- An Empirical Analysis",International Research Journal of Management and Commerce

[2] Chengalvala, Sarada. (2017). Empirical analysis of foreign direct investment (FDI) inflows into Indian economy. 4. 54-60.

[3] Singhania, Monica \& Gupta, Akshay. (2011). Determinants of foreign direct investment in India. Journal of International Trade Law and Policy. 10. 64-82. 10.1108/14770021111116142.

[4] Kaur, M., Yadav, S. S., \&Gautam, V. (2013). A bivariate causality link between foreign

[5] Aykut, Dilek \& Sayek, Selin. (2007). The Role of the Sectoral Composition of Foreign Direct Investment on Growth.

[6] Lect. Ping Zheng, Sen. (2013). The Variation in Indian Inward FDI Patterns. Management International Review. 53. 10.1007/s11575-013-0178-z.

[7] Dash, Ranjan \& Parida, Purna. (2012). FDI, services trade and economic growth in India: Empirical evidence on causal links. Empirical Economics. 45. 10.1007/s00181-012-0621

[8] Alfaro, Laura. (2003). Foreign Direct Investment and Growth: does the sector matter. 